\title{
New Kids on the Recycling Block: the Role of Supermarkets and Bodegas for Sustainable Consumer Behaviour in Lima
}

\author{
Elena Borasino ${ }^{1} \cdot$ Hanna Fuhrmann-Riebel ${ }^{2}$ (D)
}

Received: 10 August 2021 / Accepted: 17 November 2021 /Published online: 1 December 2021

(C) The Author(s) 2021

\begin{abstract}
Only $4 \%$ of total municipal solid waste in Lima is recycled. Supermarkets and bodegas are in a unique, highly relevant position for the transition towards a circular economy due to their direct influence on customers' consumption patterns. This paper explores the role of supermarkets and bodegas for consumer recycling behaviour, looking both at already implemented practices and possibilities for the future. Based on semi-structured interviews conducted with key actors in the recycling sector in 2019 and 2020, we analyse the sector regarding its main actors and their different interests, the interactions between them and the regulatory framework, as well as specific initiatives undertaken to increase recycling. We then compare the main mechanisms through which consumer recycling behaviour can be influenced between supermarkets and bodegas based on the three categories convenience, knowledge and socio-psychological factors. Our in-depth analysis outlines the different pros and cons for each of the three categories in detail.
\end{abstract}

Keywords Recycling - Sustainable consumption · Consumer behaviour · Supermarkets · Retail · Peru

\section{Introduction}

Municipal solid waste management in Lima, Peru, continues to face a series of challenges due to the city's rapid urbanization process and increasing population. Waste generation in the country's capital city is increasing rapidly, while the number of formal landfills remains the same, leading to an overflow of capacities. Between 2014 and 2019, waste generation in Lima increased by almost $12 \%$, following a continuous upward trend with a steep jump in 2017 [1]. From the 3.37 million tons of total municipal solid waste generated in Lima in 2019, 2.37 million tons (representing 70\%) corresponded to household waste

Hanna Fuhrmann-Riebel

hanna.fuhrmann-riebel@die-gdi.de

Elena Borasino

eborasino@grade.org.pe

1 Grupo de Análisis Para El Desarrollo (GRADE), Av. Almte. Miguel Grau 915, Lima 15063, Peru

2 German Development Institute/Deutsches Institut Für Entwicklungspolitik (DIE), Tulpenfeld 6, 53113 Bonn, Germany 
[1], underlining the important role of the individual consumer. ${ }^{1}$ At the same time, from a circular economy perspective, the consumer plays an active role for value creation through the recycling of materials at the individual level [2].

Municipal solid waste contains valuable materials such as plastics, glass and paper, offering opportunities for recycling. Through the recycling of these materials, energy can be saved, emissions can be reduced, and environmental sustainability can be promoted [3, 4]. Recycling has been classified as an important third pillar in the "waste hierarchy" after the prevention and the preparation for re-use of materials [5]. Moreover, as a key activity within the integrated solid waste management, it can promote a circular economy transition in developing countries [6], as in the Peruvian case. Even though single-use plastic regulations are increasing the demand for recyclable materials in Lima and recycling programmes are being implemented by local municipalities, the recycling rate in the city is still very low. It is estimated that in 2018 , only $4 \%$ of total municipal solid waste was recycled in Lima, while final disposal remained by far the most common destination [7].

Although institutional reforms are being implemented since the approval of the "Law of Solid Waste Management" in 2016, the recycling sector in Lima continues to be fragmented and lacks effectiveness [8]. From a circular economy perspective, the main actors in the recycling sector include national governments, municipalities, producers of goods, recyclers, packaging industry and citizens $[9,10]$. The retail sector is in a powerful sandwich position to influence progress. On the one hand, the retail sector interacts with producers and packaging industry and has a significant carbon footprint itself. On the other hand, retailers influence consumption patterns of consumers directly. This paper focuses on the latter lever, seeking to broaden the debate on the role of key retail actors for sustainable consumer behaviour in Lima. As Hofstetter et al. [2] point out, developing a better understanding of existing circular practices by actors in the Global South is urgently needed, and our study aims to fill this gap by focussing on key retail actors in Peru.

The retail market in Peru can be split into modern and traditional retail. Modern retail is mainly composed of three large supermarket companies; traditional retail is mainly composed of local markets and bodegas (small family-owned stores). In 2019, around $80 \%$ of the households in Lima bought their food and beverages in bodegas, which is similar to the numbers reported in 2004 [11, 12]. In the same year, over $40 \%$ of households also reported to be buying in supermarkets, which represents a strong increase from only $25 \%$ in 2004 $[11,12]$. Thus, while bodegas still remain the dominant shopping option for consumers in Lima, the popularity of supermarkets is increasing rapidly. Since the supermarketization started to take-off in the 2000s, new stores have opened continuously, covering now almost every district in Lima - a phenomenon representative for the whole Latin American region [13]. This trend of greater access to supermarkets is in line with the growth of the middle class in Peru, which shows changes in its consumption patterns that do not necessarily lead towards more environmentally sustainable outcomes [14, 15].

The influence of key retail actors on consumer behaviour can have both positive and negative consequences for sustainability. On the one hand, supermarkets face increasing national and international pressure to act more environmentally responsible, and some supermarket companies already approach sustainability as a competitive advantage. Moreover, due to their strategic location, supermarkets as well as bodegas can influence

\footnotetext{
1 In Peru, waste is classified, according to the Legislative Decree $\mathrm{N}^{\mathbf{0}} 1278$, into municipal and nonmunicipal waste. This study focuses on municipal solid waste, which is made up of household waste and waste from sweeping and cleaning public spaces.
} 
upstream producers in favour of more sustainable consumer choices [16]. Simultaneously, they can directly encourage sustainable changes in downstream consumer behaviour since many customers identify themselves with the values of the companies and the brands they buy $[17,18]$. On the other hand, however, retailers can also influence consumer behaviour in a non-sustainable way. For instance, over-purchasing is likely to be encouraged [19], with offers like "buy 3 for the price of 2" supporting the purchase of unnecessary amounts of products. Yet, to what extent the substantial power of retailers in the market turns out positively or negatively for the environment has hardly been empirically investigated this far. With our study, we aim to fill this research gap, with a particular focus on recycling.

Evidence on the role of supermarkets and bodegas for consumer recycling behaviour in Peru is sparse. Previous studies looking at recycling in Peru have concentrated mainly on analysing municipal solid waste management $[8,20]$ and the problem of informal recyclers [21-25]. Another study by Chong et al. [26] used different messages to promote household recycling behaviour in the context of a municipal recycling programme. However, scientific studies on the role of retail in particular are missing.

This paper investigates how supermarkets and bodegas can influence consumer recycling behaviour in the Peruvian case, especially Lima. We do so by, first, analysing the recycling sector in Lima with respect to its main actors and their different interests, the interactions between them and the regulatory framework that guides their actions, as well as specific initiatives from the public and private sector undertaken to increase recycling, and second, comparing the main mechanisms that can influence consumer recycling behaviour between supermarkets and bodegas based on the three categories (i) convenience, (ii) knowledge and (iii) socio-psychological factors. Thus, this work seeks to contribute to the three levels of analysis of circular economy and sustainability - micro, meso and macro — and their interrelationships as suggested in Nikolaou et al. [27] while zooming in on the micro-context of supermarkets and bodegas and their influence on consumer behaviour in particular. We base our analysis on semi-structured interviews conducted with key actors in the recycling sector in Lima in 2019 and 2020.

The paper proceeds as follows. The second section explains the analytical framework, methodology and data collection. The third section gives a brief introduction to the recycling sector in Lima, focussing on the legal and institutional framework as well as a mapping of the main actors involved. The fourth section reports our results from the comparative analysis between supermarkets and bodegas. The paper ends with a discussion and conclusion in the fifth section.

\section{Analytical Framework and Methods}

\section{Methodological Approach}

This study takes a qualitative, abductive approach [28, 29] with two analytical, iterative steps. In the first step, we reviewed the available literature, laws and regulations, corporate social responsibility (CSR) reports, NGO initiatives on recycling and circular economy and conducted first scoping interviews. The aim was to produce a comprehensive mapping of relevant actors in the recycling sector, identify key themes for following up with in-depth semi-structured interviews and develop an analytical framework.

In this first step, understanding the relevance of public-private partnership for recycling governance was important for two reasons: first, the aforementioned fragmentation 
of the Peruvian recycling system calls for more collaboration between the various actors, i.e. a systematic move towards collaborative governance. Second, full privatization or public-private approaches have become popular as a governance response in cases of public service delivery failure in various policy fields. Although the state should set the conditions for a circular economy and use its legislations so that firms adopt their transition towards it [30], the private sector can play a role not only in the management of waste including its collection and recovery, but also through voluntary agreements and communication strategies [31]. Public-private partnerships have become a common alternative to public, municipal solid waste management in many low- and middle-income countries [32]. Recycling governance in Lima follows this trend, albeit unplanned.

The second step included the conduct of semi-structured interviews and the finalization of the analytical framework for supermarkets' and bodegas' influence on consumer recycling behaviour. We conducted 18 semi-structured interviews with key informants in the recycling sector in Lima from October 2019 to March 2020. Experts included representatives of the public sector, i.e. the Ministry of Environment and local governments (municipalities), main food, beverage and packaging companies, recycling NGOs, experts from academia and the three main supermarkets operating in Peru (see Table 6 in the Appendix). Recording, data transcription and note-taking were used for documentation of the interviews.

\section{Analytical Framework}

Based on the insights from the first analytical step and following Dai et al. [33], we develop a framework with three analytical categories for understanding the role of supermarkets and bodegas for consumer recycling behaviour. These categories are (i) convenience; (ii) knowledge; and (iii) socio-psychological factors.

(i) Convenience: there is a consensus in the literature that making recycling easier and more convenient is a key determinant to increase recycling behaviour of households and encourage participation in local recycling schemes $[34,35]$. Convenience means that recycling should be accessible, affordable and accepted by the public [35]. Also, a more convenient recycling scheme should address the main barriers to recycling: time, space and effort [36, 37]. This holds for both people who already recycle ("recyclers") and people who are not yet recycling ("non-recyclers") [37, 38].

Generally, convenience, understood as reducing time, energy and effort, presents a core feature of supermarkets [18], leading to better customer experience and satisfaction [39]. Moreover, distance was found to be related to convenience in the case of bodegas [40]. In developing countries, convenience also includes the number and location of collection points for recyclable materials [41, 42]. For example, a higher density of recycling centres was found to be correlated with higher collection rates [43], and recyclers were more likely to use a drop-off site if the travel distance was shorter and was also perceived as such [44, 45].

(ii) Knowledge: information about the existence of recycling programmes, about the importance of recycling as well as the consequences of not recycling and about what, how and where to recycle present fundamental elements in promoting recycling activities. Research has shown that higher levels of environmental knowledge are associated with more sustainable plastic consumption in Peru [46]. The implementation of recycling schemes should therefore be accompanied by educational initia- 
tives [35]. Well-targeted communications, frequent messages, regular feedback and reinforcement are important elements to be considered [35, 37, 47]. Supermarkets can influence consumer recycling behaviour by using their conventional marketing communication channels in a combined and repeated way [48], such as voice prompt interventions, which were found to be related with plastic bags reduction and reusable bags adoption $[49,50]$.

Supermarkets may also influence consumer behaviour through improved consumer literacy, as they provide customers with more options and information about each product [18]. However, "knowledge burden" (i.e. too much information at the same time) should be avoided, because it may lead to consumer inertia and fatigue [51]. Also, communication in supermarkets is usually more impersonal, with consumers informing themselves by reading labels or by looking at advertising, while in traditional markets, as it is the case for bodegas, communication is more personal and direct between customers and the owner [52]. This is relevant because door-to-door promotions and face-to-face communications have found to be effective techniques to influence people's attitudes towards recycling [34]. Finally, from a developing country perspective, Khan et al. [41] suggest that although knowledge about the social benefits of recycling must be reinforced, people also seem to seek financial incentives and private benefits from recycling.

(iii) Socio-psychological factors: social norms can be an important driver of recycling behaviour [53]. By either being informed about what other people are doing or by directly observing others' behaviour themselves, people can be motivated to imitate other people's actions [33, 44, 54, 55]. Both social norms in terms of what other people do (descriptive norms) and what other people approve of doing (injunctive norms) are important in this regard [56]. Moreover, people may feel social pressure and think that to a certain extent they would be socially sanctioned if they did not comply with recycling [34]. Social interactions occur in both supermarkets and bodegas [57]. Observing what other customers purchase or how other people recycle can influence one's own behaviour [58,59]. Communication strategies of supermarkets and bodegas can make use of these findings by including elements of social norms to increase their effectiveness in encouraging sustainable consumer behaviour [44, 60].

People can also feel bad or guilty if they act against their own attitudes, beliefs or moral obligations [34, 35]. Personal moral norms are important for recycling [61]. They can be influenced by social and also legal arbitrary norms [62]. For high-effort recycling behaviours, such as bringing materials to drop-off centres, moral norms and a convenient location have found to reduce the costs associated with recycling $[34,35,44]$. Attitudes and moral norms can be affected by the amount of information that is available about recycling in stores [63] and by the way supermarkets and bodegas comply with recycling relevant laws and regulations [64]. For instance, selling alternative shopping bags in supermarkets, as a result of a plastic bag ban, facilitates behavioural change by establishing a new social norm [65]. Research has shown that both social and personal norms are influenced by cultural factors and that, in a more individualistic culture, personal norms are more important for recycling behaviour, while in a more collectivist culture, social norms are [66]. 


\section{The Recycling Sector in Lima}

\section{Laws and Regulations in the Recycling Sector in Lima}

Several laws, policies, regulations and measures are being implemented by the Peruvian government to improve municipal solid waste management as summarized in the following table (Table 1). These regulations and policy instruments can be considered as initial steps towards the implementation of a circular economy model in Lima [67, 68].

The Ministry of Environment (MINAM) is the governing body at the national level that is responsible for waste management in the country, including institutional arrangements with the private sector. Clean production agreements (CPA) are additional promotional instruments that aim to introduce a series of actions in production activities that go beyond compliance with the current legislation in order to transition towards a circular economy. In 2019, MINAM has implemented a communicational strategy for circular economy called "Clean Peru" based on three pillars: environmental education, valorisation of recyclable waste and adequate infrastructure (p 1). Although MINAM is recognized for working with different companies from the private sector and NGOs on recycling issues, there is no institutionalized space that coordinates all the efforts made by the different actors properly [b 1 , b 2, b 3, n 1, n 3].

Municipalities are by law responsible for the management of household solid waste and for ensuring an adequate provision of the cleaning, collection, transport and final disposal of municipal solid waste. They are further responsible for promoting and implementing "segregation at source programmes" and the selective collection of solid waste throughout its jurisdiction. Municipal solid waste generators, i.e. households or companies that

Table 1 Overview of laws, policies, regulations and measures implemented in Peru to improve municipal solid waste management

\begin{tabular}{|c|c|}
\hline Law/policy/regulation/measure & Aim and scope \\
\hline $\begin{array}{l}\text { Law of Solid Waste Management (Legislative } \\
\text { Decree } N^{\circ} 1278 \text { ), approved in } 2016\end{array}$ & $\begin{array}{l}\text { Focus on waste as a valuable resource and on the } \\
\text { formalization of recyclers, encouraging both } \\
\text { segregation and recycling based on the principles } \\
\text { of circular economy and of the extended producer } \\
\text { responsibility (EPR) }\end{array}$ \\
\hline $\begin{array}{l}\text { Competitiveness and Productivity National Plan, } \\
\text { approved in } 2019\end{array}$ & $\begin{array}{l}\text { Includes a policy measure for the private sector to } \\
\text { adopt circular economy production models (Gov- } \\
\text { ernment of Peru, 2019) }\end{array}$ \\
\hline $\begin{array}{l}\text { Roadmap towards a circular economy in the indus- } \\
\text { try sector (Supreme Decree No 003-2020-Pro- } \\
\text { duce), launched by the Ministry of Production }\end{array}$ & $\begin{array}{l}\text { Includes not only waste management and recycling, } \\
\text { but also lines of action to encourage sustainable } \\
\text { consumption }\end{array}$ \\
\hline $\begin{array}{l}\text { Peru's Nationally Determined Contributions } \\
\text { (NDCs) in the waste sector }\end{array}$ & $\begin{array}{l}\text { Include solid waste segregation and valorization } \\
\text { mitigation measures to reduce carbon emissions }\end{array}$ \\
\hline Single-use plastic law, effective since 2018 & $\begin{array}{l}\text { Regulates the consumption of single-use plastics and } \\
\text { is considered to be a key milestone in broadening } \\
\text { the discussion on solid waste management in Peru }\end{array}$ \\
\hline
\end{tabular}

\footnotetext{
${ }^{1}$ Although the scope of EPR is defined in the law, it is still in its early stages of implementation and will first apply to electrical and electronic equipment waste only. In 2019, a Special Regime for the Management of Waste Electrical and Electronic Equipment was approved through the Supreme Decree N ${ }^{\circ}$ 009-2019MINAM.
} 
produce the same types of solid waste, are obliged to deliver the properly segregated waste to the municipalities that provide the services. The law also includes the promotion of public-private partnerships in solid waste management, although these are so far concentrated on the development of investment projects. Solid waste management can be carried out by private actors, i.e. authorized solid waste operators, through collaboration agreements and specific contracts. However, recycling is mainly undertaken by informal recyclers $[\mathrm{b} 1, \mathrm{~s} 1$, $\mathrm{n} 2, \mathrm{n} 4]$. It is the responsibility of the municipality to formalize them.

\section{Key Actors in the Recycling Sector in Lima}

From a circular economy perspective, different actors participate in the recycling sector in Lima (Fig. 1). All of these actors play an important role for the transition towards a circular economy to be successful. Supermarkets and bodegas are strategically located between consumers, brand companies, packaging producers and municipalities, which offers great potential to become a central player in the recycling sector in Lima. In this section, we briefly outline the main interactions between the different actors, as well as their different perspectives and motives.

For packaging producers, recycling is becoming a central part of their business. Some producers have their own recycling plants where materials that can then be used for their

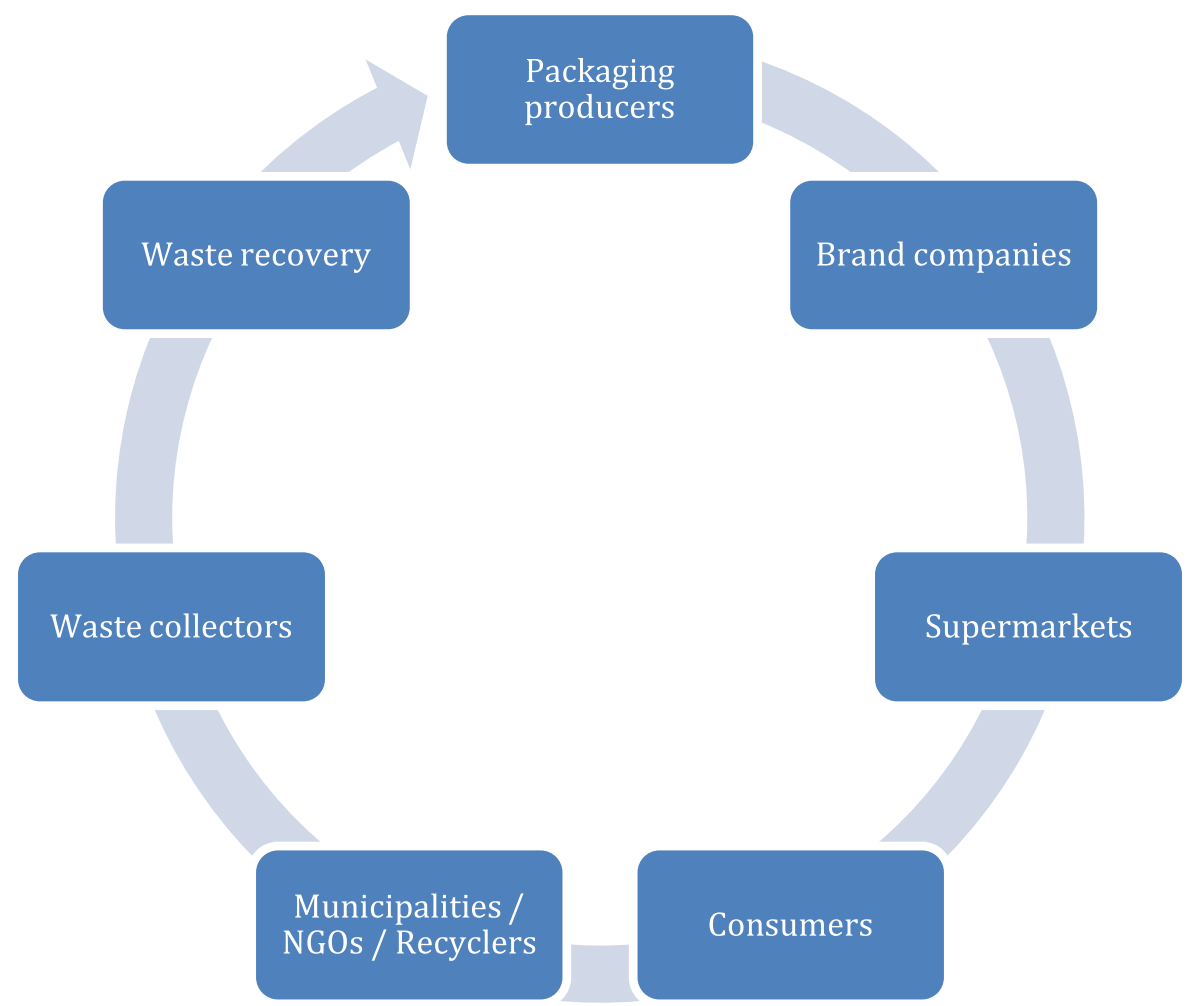

Fig. 1 Main actors in the recycling sector from a circular economy perspective in Lima, Peru. ( Source: authors' own illustration based on Ferronato et al. [67]) 
own products are recovered [b 1]. Packaging producers sell their products to supermarkets and sometimes also partner with them in recycling campaigns [b 1]. They are influenced by big brand companies, which aim to produce recyclable packaging for their products [b 1]. One of the main challenges for packaging producers is that post-consumer waste recovery in Lima is minimal; thus recyclable waste, as their main input, is still scarce [b 1, b 2, s 1]. This is problematic from a circular economy perspective, as packaging producers very much rely on consumers' decision to recycle ("we depend on the final consumer") [b 1].

Main food and beverage companies in Lima are advancing with regard to recycling as they are influenced by global groups of companies, of which they are often part of, as well as national regulations [ $\mathrm{b} 1, \mathrm{~b} 2, \mathrm{~b} 3]$. They have established concrete goals for their products to become recyclable [b 2, b 3]. One of their main interests is that a larger and better market for packaging will develop, so that the opportunities to produce sustainably from recyclable materials will improve [b 2, b 3]. They mainly work together with NGOs, packaging producers and supermarkets [b 2, b 3]. One of the companies interviewed is one of the two most important beverage companies in Peru that have voluntarily signed a CPA in the area of solid waste with MINAM. This does neither replace the legal obligations established by environmental regulations nor does it encourage cooperation between several actors though, as agreements are signed between the company and MINAM only [s 1]. It may be, in part, the result of understanding sustainability as a competitive advantage from a company perspective [ $\mathrm{b} 2, \mathrm{~b} 3]$ due to both an increasing international debate around the topic and increasing awareness among consumers.

Supermarkets are becoming increasingly aware of the materials they use from a circular economy perspective of "closing cycles" and of the responsibility they have towards the consumer [s 1]. They work closely together with their packaging providers with the aim to include higher proportions of recyclable materials in their own packaging [b 1, s 1, s 2, s $3]$. However, the main challenge from their perspective (similar to packaging producers) is that people do not recycle [s 1, s 2, n 4]. There is not enough material to be collected, and so far, both market and industry are only developed for a few types of recyclable materials. Supermarkets sometimes participate in communication campaigns for recycling and sustainable consumption together with NGOs, MINAM, municipalities and other companies, such as the same two beverage companies that signed a CPA with MINAM [s 1, s 2]. Despite all these initiatives, there is no formal alliance between companies in general or between supermarkets in particular yet [s 3]. Most of them work with the public sector, MINAM and municipalities in a more bilateral way. In general, there are hardly any campaigns where more than one company, offering similar products or services, participate together [s 3]. As mentioned above, a reason may be that sustainability is seen as a competitive advantage, an idea that is supported by supermarkets' investors [s 1]. The existing public-private partnerships between supermarkets and other actors in the sector have the advantage of generating recycling capabilities and successful recycling governance in the absence of a fully effective public service model, while it may omit the inclusion and active participation of other key actors in the chain.

Municipalities are a key actor for recycling in Lima but at the same time are faced with general budget restrictions [p 2, p 3]. To address this, the Ministry of Economics and Finance is providing them with additional funding through an incentives scheme, which is conditioned on the implementation of segregation at source programmes (among other specific targets). Despite the fact that municipalities have started to implement these programmes, the uptake of neighbours as well as the amount of the materials collected is still rather low. For example, only around $12 \%$ of households take part in the recycling programme of the middle/upper class neighbourhood Miraflores [p 4]. 
Municipalities that have implemented their segregation at source programmes interact directly with households and work with formal associations of recyclers who are in charge of the recovery of the recyclable materials. In some cases, companies and supermarkets participate in these municipal recycling programmes as well. Municipalities also work together with NGOs for the implementation of drop-off stations in public spaces [p 2]. NGOs perceive themselves as articulators between the public and the private sector $[\mathrm{n} 1, \mathrm{n}$ $2, \mathrm{n} 3]$. They organize educational and participatory campaigns with different stakeholders and implement recycling stations for companies and supermarkets. NGOs also become a link between companies and supermarkets, as well as formal associations of recyclers. Formal recyclers are the ones who benefit from the recyclable materials collected at the recycling stations [s 2]. NGOs support the formalization of recyclers [s 2, n 2]. The Ministry of Production is considered to be crucial for the sector but is less active up to now [s 2, s 3].

The current system offers several options to improve circularity along the value chain that go beyond reverse logistics, ranging from the input of materials over the recovery and packaging, both upstream (producers, e.g. food packaging) and downstream (consumers, e.g. shopping bags), to the final disposal. The presence of an informal recycling market puts an additional challenge on the sector to work successfully. A closer analysis of current practices and capabilities of both supermarkets and bodegas to encourage consumer recycling behaviour will show which (dis-)advantages for recycling quotas, material recovery, financial equity and power (im-)balances between the different stakeholders currently exist.

\section{The Role of Supermarkets and Bodegas for Recycling Behaviour}

\section{Current Practices by Supermarkets and Bodegas}

The three supermarkets operating in Lima approach the topic of recycling and sustainability in different ways (Table 2). Supermarket 1 is the most ambitious with respect to its sustainability goals. For this supermarket, sustainability is part of its cultural identity [s 1]. In 2019, this supermarket operated 108 stores in Lima. Supermarket 2 is also committed to integrate sustainability into its business model [s 2], but it carries out fewer activities compared to supermarket 1 , with a performance more similar to supermarket

Table 2 Current practices by supermarkets to promote recycling and sustainability ( source: authors' interviews and sustainability reports)

\begin{tabular}{llll}
\hline Current practices & Supermarket 1 & Supermarket 2 & Supermarket 3 \\
\hline Recycling stations & $\checkmark$ & $\checkmark$ & $\mathrm{x}$ \\
Education campaigns on sustainability \& recycling & $\checkmark$ & $\checkmark$ & $\checkmark$ \\
Packaging improvements & $\checkmark$ & $\checkmark$ & $\checkmark$ \\
Complying with regulations & $\checkmark$ & $\mathrm{x}$ & $\mathrm{x}$ \\
Working with providers on sustainability issues & $\checkmark$ & $\checkmark$ & $\mathrm{x}$ \\
Internal waste management & $\checkmark$ & $\mathrm{x}$ & $\checkmark$ \\
Recycling contests between stores & $\checkmark$ & $\checkmark$ & $\mathrm{x}$ \\
Food and organic waste management & $\checkmark$ & $\mathrm{x}$ & $\mathrm{x}$ \\
Reverse logistics & $\checkmark$ & $\mathrm{x}$ & \\
Sustainability training with employees \& collaborators & $\checkmark$ & & \\
\hline
\end{tabular}


3. In 2019, supermarket 2 operated 93 stores in Lima. Supermarket 3 is the only supermarket that has not yet implemented recycling stations in its stores. Supermarket 3 operated 77 stores in 2019 in Lima.

Among several sustainable practices that supermarkets are implementing in order to increase consumer recycling behaviour, educational campaigns and recycling stations in their stores are the most common ones. Also, as mentioned before, supermarkets regularly participate in sustainability campaigns with NGOs, municipalities and other companies. Complying with the relevant regulations described in the previous section, improving their packaging processes and managing their waste internally are also shared initiatives among the three supermarkets companies. Regarding the legal framework and packaging, supermarkets 1 and 2 went a step further and increased the proportion of recyclable plastic within their packaging over $30 \%$, beyond what is established by the law (15\%) [s 1, s 2]. Their strategic interest is that by doing so, in the long run, they can improve their reputation through the marketing of their initiatives and achievements [s 2]. Supermarket 1 implements additional sustainable practices throughout its supply chain and internally with its employees, making sustainability an important part of its corporate governance. For instance, it is implementing reverse logistics, which means that the same truck that delivers and supplies the stores is in charge of bringing back all the boxes and packaging materials used as well. Moreover, it invests in sustainability training among its employees and collaborators and organizes recycling contests between different stores to increase motivation and ownership for the topic.

Compared to supermarkets, bodegas are so far not active in fostering sustainable behaviour among their customers. A main reason is that bodegas are less regulated and have a lower pressure from society to comply with the law, which, for example, allows them to continue to provide free plastic bags [b 1, s 3]. Yet, we find that different mechanisms that are important to influence recycling behaviour could be provided both by supermarkets and bodegas. Bodegas tend to compete through differentiation [s 1], through personal relationships with their customers and through the marketing support they receive from their providers [b 1]. In the following, we analyse the role of supermarkets and bodegas for sustainable consumer behaviour according to the different categories presented above.

\section{Analysis According to Categories}

\section{Convenience}

Supermarkets Direct and easy access to the recycling stations is an important aspect for the convenience among consumers. As shown in Table 1, two of the three supermarkets companies have implemented recycling stations in their stores. The stations are usually placed in the parking lots of the supermarkets for space reasons. Thus, they are mostly targeted at customers that go to the supermarket by car, based on the common assumption that most customers use their car to bring their recyclable materials to the stations [s 2]. Yet, supermarkets risk to miss out on customers that do not come by car and therefore do not see the recycling stations immediately. It may be useful for supermarkets to make the stations more visible also for customers that come by other transport modes to increase convenience for these consumers as well [b 3]. 
Simplicity presents another important aspect for convenience once consumers are in front of the recycling stations. It is often challenging for customers to find so many different recycling containers at one recycling station [s 1]. Usually, there are separate containers for cans, plastics (PET), hard plastics, glass and paper. Too many containers increase the level of effort for consumers to sort their waste as it involves having a solid knowledge to separate the materials appropriately and place them in the correct containers [s 1]. This complexity can greatly reduce the convenience for people to recycle, especially among less educated consumers.

Regarding the quality and maintenance of recycling facilities, it is important for the convenience among consumers that the recycling stations are clean [s 1]. In higher-income districts, recycling stations are usually better taken care of and supermarkets often offer hands' washing gel at stations, thereby improving the convenience in terms of cleanliness. They are investing in measures to avoid that recycling stations could be perceived as dirty and to make sure that they stay hygienic. This is also relevant from the supermarket's perspective. When the containers are filled and people decide to simply place the materials somewhere else, waste ends up on the ground, causing hygienic problems. In the case of supermarket 3, they used to offer recycling stations at some stores yet then decided not to implement them any longer because they struggled to keep them clean. This problem was so severe that it even led to the closure of certain of their stores [s 3]. In lower-income districts, it is still less common for people to recycle in general. Therefore, recycling stations at supermarkets are usually used less frequently, which again leads to insufficient maintenance [s 1]. This reduces the convenience for those people who still want to use the recycling stations in lower-income districts, which points towards a vicious circle that needs to be overcome.

Supermarkets can also play a role in increasing the convenience for people who are already participating in municipal segregation at source programmes. Municipalities' programmes normally collect the materials once a week, but for some households, this is not enough or not that effective [s 1]. Therefore, the recycling stations at supermarkets present a complementary option for frequent recyclers, thereby increasing the overall amount that is recycled. Moreover, for those people who want to recycle but who live in districts where there is no segregation at source programme offered by the municipality, supermarkets' recycling stations can be the only alternative they currently may have (Table 3) [b 1].

Bodegas Bodegas are perceived by most of the interviewees to be closer to the consumer and part of the community. As one company interviewee said: "it is easier to find a bodega than to find a garbage bin in the streets" [b 3]. There are bodegas on every one or two blocks in Lima. This proximity is related to the frequency and the volume of the purchases made. It is common that customers buy almost daily at bodegas, since their purchases are mainly for direct consumption or for small replenishment. Customers usually consume less [b 3] and more frequently at bodegas compared to supermarkets [40]. So far, it is not common that bodegas are involved in any recycling activities. However, the close proximity of bodegas, both regarding their location and their relationship with their customers, could greatly increase the convenience for people to recycle. In contrast to supermarkets, consumers could easily bring their recyclable materials to bodegas by foot and, on a more frequent, perhaps even daily basis, which would further reduce the necessity for people to store their recyclable materials at their homes for a longer period. Thus, bodegas could have an important role in encouraging recycling continuity [b 3]. Moreover, since bodegas are well-known within their neighbourhood, it would become easier for many people to 


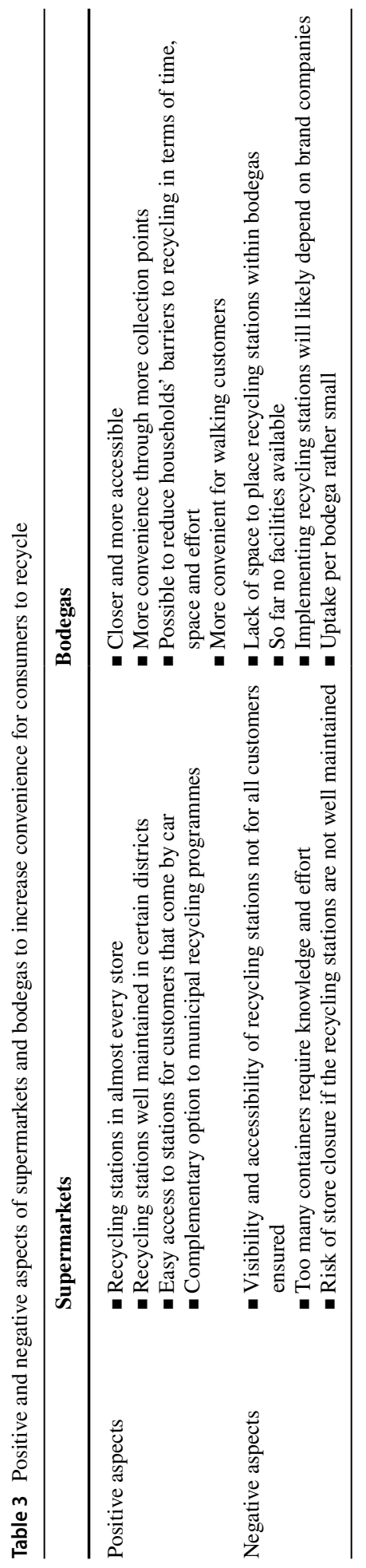


recycle if they could associate recycling stations with bodegas, as consumers would be more familiar with where to go [s 1].

Although recycling may become more accessible and simpler if it was related to bodegas, there is less consensus among our interviewees on whether bodegas would have the necessary infrastructure to supply the required facilities such as recycling stations. The main problem is that bodegas are usually very small and do not have enough space to place different recycling bins within their stores [b 3, s 1]. It seems unlikely that bodegas could serve as a full alternative to municipal recycling programmes or recycling stations at supermarkets where people could bring large amounts of materials at the same time [b 3]. What might be more realistic is that bodegas could become a place to directly return what has been consumed - either within the bodega itself or outside on the street [s 3, b 3]. This would require, however, that the materials were collected from the bodegas by formal recyclers or the municipality on a regular basis. Recycling bins could be placed outside the store on the street, which would further increase the visibility for people who are passing by. The "return what you consume" idea would greatly fit the typical consumption patterns associated with bodegas and could be a great addition to already existing recycling programmes and stations. It could further address households' potential limitations to recycle in terms of time and space, when the options to stockpile materials at home or to transport them to a distant recycling station are limited or when the collection through a municipal recycling programme is not frequent enough or not existent [b 1]. Moreover, as in the case of supermarkets, especially in low-income districts where there is often no recycling programme offered by the municipality, bodegas could become an entry point to the topic for those people who have not been familiar with it before.

Despite these promising conditions for bodegas to become more involved in recycling activities, efforts to implement recycling stations will probably not come voluntarily from bodegas out of their own initiative [b 1, s 1]. Instead, it seems more likely that brand companies would lead this process [b 1, s 3]. Bodegas are often used and influenced by companies to showcase certain products, and recycling stations could become another aspect of their commercial strategy with bodegas. The supply of recycling facilities in bodegas might therefore be rather volatile and dependent on companies' preferences, unless companies were required to take part in an EPR system by law in the future. An alternative approach could therefore be for bodegas to become part of municipalities' recycling programmes in the district where such programmes are offered [b 3].

\section{Knowledge}

Supermarkets Supermarkets are important places for communication, education and diffusion of information. This offers great potential for supermarkets to be an important actor to increase knowledge about recycling among consumers. Supermarkets have several communication channels already established with their customers that can be used to provide information about recycling, such as audios within stores, hang advertisements in corridors or social media channels [s 2]. Many supermarkets are including sustainability criteria within their marketing and commercial strategies already when deciding which products and brands they offer [s 2, s 3]. Communication to promote recycling should be phrased as simple as possible using "easy" words and avoiding complicated terminology [s 1]. Supermarkets can also address knowledge about convenience by communicating that recycling is easy and that it does not require a lot of effort [s 1, s 2]. 
As described in the previous section, supermarkets sometimes partner with other actors for specific recycling campaigns, which is also a way to increase knowledge among consumers. For example, supermarket 1 commented that they regularly work together with several national and international brand companies, NGOs, municipalities and MINAM to make products with recyclable packaging more visible to consumers. The aim of these campaigns is to promote knowledge about recycling but also about sustainability in general. The campaigns often include special activities taking place at the recycling stations of supermarkets to help people understand the different categories of recyclable materials. The hope is that by doing so, the convenience for consumers to use the recycling stations will increase as well.

Moreover, the outreach of supermarkets' communication strategies can go beyond the recycling facilities within their stores alone. Supermarkets can become a platform that provides combined information about the different recycling options that are available to consumers [s 3]. Therefore, supermarkets are also important partners to municipalities in their efforts to promote recycling behaviour [s 1, s 3]. The communication outreach of municipalities is often very limited [s 2], and in many cases, only few people are aware of the existence of local segregation at source programmes [b 3] or recycling stations in public spaces [s 3]. Through more cooperation with municipalities, supermarkets could amplify information about the existence of these programmes and facilities. At the end, the supermarket customer "is the same neighbour that could participate in the municipal programme" [s 3].

A potential challenge can be that supermarkets often provide a lot of information at the same time, which can lead to confusion among consumers. This applies not only to information overload in terms of recycling and sustainability messages, but also - and more importantly — to unsustainable and commercial messages (promotions, discounts, etc.). This can make it difficult for consumers to focus on the key content of the individual messages that aim to promote recycling behaviour, which can reduce their effectiveness (Table 4).

Bodegas Bodegas are an important channel of communication to consumers as well. Especially for food and beverage companies, they provide an important platform as bodegas are the main sales and marketing channel of their products: between 50 and $70 \%$ of their sales are made through bodegas [b 3, s 1, s 3] [69]. These companies are the main providers of bodegas and usually have a strong interaction with them. As important channels of communication, bodegas are often full of ads of these companies and their products. Due to this strong influence of companies on bodegas, knowledge diffusion about recycling will depend on these companies' preferences as well.

A challenge is that bodega owners often do not have the required knowledge about recycling themselves. Thus, brand companies would have to play a crucial role in educating consumers about recycling within bodegas [s 3, b 1, b 3]. They could use their marketing influence within bodegas to do so and take advantage of the extensive outreach bodegas have since they are located "everywhere" [b 1, b 3]. Most interviewees perceived that the interaction between bodegas and company suppliers is the relationship through which bodega owners could learn more about recycling themselves, be able to adopt recycling practices and ultimately influence consumers' recycling behaviour by increasing their knowledge as well. 
Table 4 Positive and negative aspects of supermarkets and bodegas to increase knowledge among consumers to recycle

\begin{tabular}{|c|c|c|}
\hline & Supermarkets & Bodegas \\
\hline Positive aspects & $\begin{array}{l}\text { Different channels of communication already established } \\
\text { with their customers } \\
\text { - Participation in campaigns with different actors involved } \\
\text { to increase knowledge } \\
\text { - Education about sustainability in general } \\
\text { - Dissemination of information about municipal segrega- } \\
\text { tion at source programmes and other recycling facilities } \\
\text { possible }\end{array}$ & $\begin{array}{l}\text {-Main channel of } \\
\text { communication } \\
\text { of different brand } \\
\text { companies } \\
\text {-Extensive outreach } \\
\text { as they are located } \\
\text { everywhere } \\
\text {-Frequent interaction } \\
\text { and communica- } \\
\text { tion } \\
\text {-Information trans- } \\
\text { mitted in a more } \\
\text { personal way } \\
\text {-Direct influence on } \\
\text { their customers' } \\
\text { buying decisions }\end{array}$ \\
\hline Negative aspects & $\begin{array}{l}\text { - Potentially too much information } \\
\text { - Also advertisement of non-sustainable practices }\end{array}$ & $\begin{array}{l}\text {-Dependent on the } \\
\text { support of the } \\
\text { brand companies } \\
\text {-Often limited } \\
\text { knowledge of } \\
\text { bodega owners } \\
\text { themselves }\end{array}$ \\
\hline
\end{tabular}

Moreover, companies often support bodegas in strengthening their administrative and commercial skills [b 3, s 1]. In exchange, they expect bodegas to recommend their products to consumers. This support could be extended to environmental issues. It is perceived that recycling issues should have the same importance in this regard as commercial issues [b 3]. Thus, in exchange for recommending their products, brand companies could offer environmental education to bodega owners and raise their awareness for recycling. However, it seems that the best way to do this will likely be by highlighting the social and health benefits of recycling, above the purely environmental ones [b 3].

Considering the consumption patterns in bodegas with more frequent purchases, information about recycling could be transmitted more regularly as well. In addition, information disseminated within bodegas would have the advantage that it could be transmitted face to face in a more personal way due to the close relationship that customers often have with the owner. Because of this close connection, bodega owners often influence their customers' buying decisions [s 1, b 3]. Thus, if bodegas decided to engage more in the topic in the future, supported by their providers, they would have great potential to influence their customers' recycling behaviour.

\section{Socio-Psychological Factors}

Supermarkets When customers go to supermarkets, they find themselves in an environment where they can directly observe how other people are behaving, for example, if they are purchasing more products made of recyclable materials or if they are using less plastic bags. In the same way, supermarkets' recycling stations can become a place for social 
norms to develop as customers can observe how other recyclers sort their waste, which can not only improve their own knowledge but also change their perception about the importance of recycling. Such observations can increase the perceived social norm about recycling and about the importance of the topic. Thus, supermarkets can become important places where social norms towards recycling can be transmitted, both regarding descriptive and injunctive norms, and where personal moral norms can be developed. Yet, social influence in supermarkets can also go in the other direction, if many people do not behave sustainably and the observation of others suggests an unsustainable norm. Mandatory regulations can support the positive effects by being an important driver for supermarkets to adopt sustainable practices [s 3]. For instance, supermarkets have to comply with regulations that tax plastic bags, increase the recyclable plastic content in packaging and mandate the provision of reusable bags. As mentioned before, supermarkets not only comply with these regulations but in some cases also go further [s 1, s 2]. This compliance with the legal requirements can facilitate consumers to internalize sustainable consumption patterns.

Regarding the inclusion of normative elements in supermarkets' communication strategies, appeals on social norms are not common (none of our supermarkets' interviewees reported to do so), which might in part be due to the still rather low recycling rate, i.e. the fact that there is no descriptive norm in recycling (yet). However, there is evidence that the injunctive norm, i.e. the social approval for recycling, is already very high in Lima, ${ }^{2}$ which might be useful for supermarkets' communication strategies. Moreover, appeals on dynamic norms in recycling, i.e. the fact that recycling behaviour is growing in Lima, might be a promising element to motivate customers to recycle [70, 71]. Supermarket 3 reported to include elements aimed at addressing personal moral norms in its communication by appealing on the importance of recycling [s 3]. This leaves room for potentially more effective communication strategies based on social influence in the future.

It is important to note that attitudes towards recycling are different between consumers. For example, in high-income districts in Lima, people often recycle because of its positive social image and reputation [s 1]. Customers believe that "it makes you fit in if you recycle" [s 1], highlighting the importance of the perceived social norm in recycling. Thus, supermarkets could make use of this positive image of recycling and empower customers to do so [m 2]. Many consumers are already environmentally concerned and thus have beliefs and values that are consistent with recycling practices [m 2]. This is one of the reasons why it was better accepted by customers from higher-income districts to start paying for plastic bags when the new law was introduced [s 1]. On the other hand, in low-income districts in Lima, the perception is that recycling should have an economic value [s 1]. Supermarkets' role in these regions may differ and focus more on strategies that make customers value recyclable materials. This could mean that supermarkets might even need to pay people to recycle or make them aware that they can make money out of it. For instance, supermarket 1 is planning to implement reverse vending machines in lower-income districts to provide some economic incentives for recycling (Table 5).

Bodegas As mentioned before, one of the most important features of bodegas is that they are perceived as part of the community. Most of the interviewees agreed that

\footnotetext{
2 In a survey that was conducted with 100 households in the district of Miraflores in Lima as preparation for another study [71], 97\% of all households said that they think recycling is important for protecting the environment, indicating a strong injunctive norm.
} 
Table 5 Positive and negative aspects of supermarkets and bodegas to increase socio-psychological factors among consumers to recycle

\begin{tabular}{|c|c|c|}
\hline & Supermarkets & Bodegas \\
\hline Positive aspects & $\begin{array}{l}\text { Environment where social norms in } \\
\text { recycling can be observed and personal } \\
\text { moral norms can be developed } \\
\text { - Compliance with waste regulations } \\
\text { facilitates the internalization of sustain- } \\
\text { able consumption patterns } \\
\text { - Some communication strategies aim to } \\
\text { address personal moral norms } \\
\text { - Positive attitudes towards recycling in } \\
\text { high-income regions can be reinforced }\end{array}$ & $\begin{array}{l}\text { - Long and trustworthy relation- } \\
\text { ship of bodega owners to their } \\
\text { customers } \\
\text { - Information transmitted in a more } \\
\text { personal way } \\
\text { - Strong identification of custom- } \\
\text { ers with other people (reference } \\
\text { group) that buy in the same } \\
\text { bodega }\end{array}$ \\
\hline Negative aspects & $\begin{array}{l}\text { - For some customers, especially in low- } \\
\text { income districts, monetary incentives } \\
\text { will be more important } \\
\text { - Communication strategies based on } \\
\text { social norms should still be explored } \\
\text { - Communication rather distant }\end{array}$ & $\begin{array}{l}\text { Economic benefits from recycling } \\
\text { remains uncertain, thus less } \\
\text { motivation for bodega owners to } \\
\text { engage in it } \\
\text { - Lack of legal regulations that } \\
\text { mandate sustainable practices to } \\
\text { be transmitted to consumers }\end{array}$ \\
\hline
\end{tabular}

customers maintain a loyal and often life-long relationship with the owners, which creates a relationship of trust. For example, it is common that customers are able to pay the bodega owner later if they don't have the necessary money at the moment of purchase. This personal relationship offers great potential for bodega owners to influence their customers' personal attitudes and moral norms towards recycling. It is likely that customers would start to adopt recycling practices if it was recommended to them by their trusted bodega owner from around the corner. Moreover, seeing other people recycle within bodegas could have great effects since the reference group would mainly constitute people from the same neighbourhood, with which people could directly identify. Research has shown that group identity and personal communication are key elements for the effectiveness of social norms [72], which makes bodegas a very suitable environment for social norms in recycling behaviour to develop. In the same way, if bodegas decided to promote recycling behaviour through communication strategies within their stores, including social norm information about the recycling behaviour of other customers within the same bodega may be promising.

A challenge perceived by our interviewees is, however, that bodega owners might be more interested in recycling if they received certain economic benefits from it [b 3, s 1]. As long as this is not the case, it seems less probable that they would encourage any moral obligations towards recycling among their customers. When thinking about how to influence bodega owners to adopt recycling practices, "more income and less effort" [b 3] are expected to be the most important arguments. However, whether bodegas could benefit economically from recycling activities remains uncertain. There is no consensus among the interviewees on the question whether bodegas could have economic benefits from additional sales of customers that visit the bodegas more often because they want to recycle or from the amount of materials they could collect [b 1, b 3, s 1]. Again, it seems most 
likely that the push for adopting recycling practices would have to be initiated by the bodegas' providers [b 1, b 3]. Moreover, if bodegas were more regulated by the law, it would require them to adopt more sustainable practices, which could then be transmitted to and internalized by their customers as well.

\section{Discussion and Conclusion}

This paper analyses the role that supermarkets and bodegas already have and potentially could have to foster recycling and sustainable consumer behaviour in Lima, Peru, looking both at already implemented practices and possibilities for the future.

Our actor mapping confirms that the recycling sector in Lima is fragmented and current actors fail to deliver effectively, despite the implementation of new laws and regulations. Different public and private actors are involved in recycling activities, yet there is no institutionalized space that coordinates all the individual activities properly. Two main challenges for more systematic public-private cooperation prevail: first, sustainability presents a competitive advantage for companies, impeding cooperation to some extent, and second, households' recycling volume is too low, impeding market growth for recycling material.

Supermarkets and bodegas are in a unique, highly relevant position for the transition towards a circular economy due to their direct influence on customers' consumption patterns. Supermarkets in Lima are very active already, collaborating with many key actors in the sector. They offer recycling stations in their stores and engage in waste management and recycling campaigns with varying intensity. To some extent, supermarkets thus fill a governance gap, coordinating efforts among public and private actors. Bodegas are less active yet but have enormous potential due to their close, long-established relationships with both customers and supplying companies. Receiving the companies' support will be key for bodegas to exploit their potential role in promoting recycling behaviour among consumers.

Purchase levels and compliance present key structural factors impacting (non-)sustainable consumption choices. Supermarkets tend to encourage higher levels of purchases than bodegas but are more regulated by and compliant with waste management policies. This can facilitate consumers to internalize these regulations, for example, regarding the singleuse plastic law. Bodegas, in turn, encourage smaller purchases, resulting in lower levels of waste. Yet, bodegas tend to not comply with any laws or regulations on waste management and continue to provide free plastic bags.

Our in-depth analysis shows that both supermarkets and bodegas have different advantages and disadvantages to influence consumer recycling behaviour regarding each of the three categories investigated. With respect to convenience, the accessibility and cleanliness of recycling facilities are key in supermarkets. So far, easy access to recycling stations is mainly ensured for customers who come to the stores by car yet less so for other transport modes. There is a clear gap between the maintenance of recycling stations and thus the convenient usage for customers in higherincome regions compared to poorer areas. A general challenge represents the high number of different containers, which requires effort and knowledge to sort the different materials properly. Given these different conditions of recycling convenience in 
supermarkets for different customer types (car vs. non-car users, high- vs. low-income regions, knowledge vs. no knowledge), uneven levels of uptake of recycling behaviour among consumers are resulting. Bodegas are in themselves convenient because they are perceived to be close and accessible, though usually lack the space to recycle large amounts of products and are so far not offering any facilities. If the structural barriers towards recycling within bodegas could be overcome, most likely through the help of their providers, bodegas could become a convenient location for recycling especially for walking customers. Moreover, bodegas could offer the option for more frequent recycling, which would address the potential problem for people to stockpile large amounts of materials at home.

With regard to knowledge, supermarkets are in a good position to reach their customers as they already have several communication channels established. Supermarkets have started to use their various outreach options to expand knowledge on recycling (in-store, recycling stations, ongoing campaigns with other actors), which can also have positive effects on the convenience for consumers to recycle. A challenge is that information may get lost in the overflow of general advertising within supermarkets' stores. Communication within bodegas is greatly dependent on their providing companies' preferences. Bodega owners often lack the required knowledge about recycling themselves yet have a high chance for effective outreach due to their more personal, frequent mode of communication with their customers. Receiving their providers' support in acquiring own knowledge first will be important for bodegas to start communicating about recycling to consumers.

Regarding socio-psychological factors, supermarkets constitute an environment where customers can directly observe how other people are behaving, offering opportunities for recycling norms to develop. So far, communication strategies are partly aimed at addressing personal moral norms, though do not make use of social norms, which leaves room for improvement. Varying attitudes towards recycling between higher- and lower-income regions suggest that differentiated communication and incentive strategies will be needed. Bodegas have the great advantage of having a close relationship with their customers, which offers the opportunity to emphasize the importance of recycling and address moral norms in a more personal way. Moreover, people identify themselves with the other customers that buy in the same bodega so that the reference group, through which recycling norms could be observed, is more relevant. The main challenge is that the incentive for bodega owners to adopt recycling practices and communicate about its importance to their customers may be low as long as there are no direct financial benefits associated with it. It seems only realistic that the push for recycling would have to be initiated by the bodegas' providers or be mandated by legal requirements.

Our results have important policy implications. With economic growth and the rise of the middle class in Peru, consumption patterns change, and findings ways to encourage sustainable behaviour is key [14]. Our paper shows how supermarkets and bodegas each have strategic advantages in encouraging sustainable consumption, in particular recycling behaviour, among their customers by increasing the convenience for people to recycle, by increasing knowledge about the topic and by activating personal moral norms and social norms in recycling. If used strategically by policy makers, bodegas could become important entry points to the topic especially for people in 
lower-income regions where environmental literacy among consumers is still low. Educating and incentivizing bodega owners first as well as involving supplying companies and extending mandatory regulations will be key in this regard. The government should become more involved in empowering bodegas to become a central actor in the recycling sector in Lima and to reduce their dependency on their supplying companies' preferences in order to foster a more equal distribution of power in the sector. Municipalities could organise knowledge exchange to balance knowledge gaps, foster mutual learning between supermarkets and bodegas and, thus, indirectly, contribute to make the system more egalitarian. A more systematic set-up of reverse logistics along the value chain in a way that connects bodegas, supermarkets and producers could be helpful. Both supermarkets and bodegas would then have a fixed forward and backward integration into the chain, allowing for stable economic revenue and avoiding the crowding out of bodegas. For such a system to succeed, structural barriers for bodegas to recycle, especially in terms of space, would need to be overcome. Closer cooperation between bodegas and municipalities should be pursued given the municipalities' ownership for the topic and their often already established recycling programmes, in which bodegas could be (compulsorily) integrated. Making use of economic incentives to engage bodega owners in the topic might be promising, beyond applying regulations. The role of supermarkets in the recycling sector should be strengthened and their strategic location and extensive network used more heavily to promote recycling beyond their own stores. Since regulatory supervision is already prominent in the case of supermarkets, it could be used by policy makers not only to enforce strict compliance with the rules of supermarkets themselves, but also to enhance greater collaboration between different actors and establish new key public-private partnerships. While strong public-private partnerships between supermarkets and other actors, such as brand companies or the government, are likely to benefit the overall recycling system, they may also have the potential disadvantage of excluding other key actors along the value chain, so that an egalitarian establishment should be ensured. Joint campaigns with supermarkets and other actors from the public and private sector should be intensified to promote joint knowledge creation and raise awareness for the topic. Moreover, the supply and proper maintenance of recycling stations at supermarkets should be ensured also in lowerincome regions in order to avoid that recycling remains a topic mainly for consumers in higher-income regions.

Our paper shows how supermarkets as well as bodegas would have the potential to become change agents for encouraging consumer recycling behaviour in Lima if their efforts were combined and used most effectively. We thus shed light on one important piece in the puzzle for the successful transition towards a circular economy in Peru. Future research may want to look at the behaviour change determinants for recycling of other key actors in the recycling sector as identified in our actor mapping, as we zoom in on the role of key retail actors in particular. Moreover, given that recycling is only one of the five pillars in the "waste hierarchy" [5], more research on the other four pillars will be needed to promote circularity along the whole value chain and ensure a sustainable waste and resource management in the country. 


\section{Appendix}

Table 6 Overview of interview partners and dates

\begin{tabular}{|c|c|c|}
\hline Type of actor & Institution & Interview date(s) \\
\hline \multicolumn{3}{|l|}{ Public sector } \\
\hline p 1 & Ministry of Environment & October 30, 2019 \\
\hline $\mathrm{p} 2$ & Municipality 1 & October 21, 2019 \\
\hline p 3 & Municipality 2 & October 21, 2019 \\
\hline $\mathrm{p} 4$ & Municipality 3 & October 18, 2019 \\
\hline \multicolumn{3}{|l|}{ Business } \\
\hline b 1 & Packaging company & $\begin{array}{l}\text { October } 17,2019 \\
\text { March 9, } 2020\end{array}$ \\
\hline b 2 & Beverage company & October 29, 2019 \\
\hline b 3 & Food company & $\begin{array}{l}\text { October 24, } 2019 \\
\text { March 17, } 2020\end{array}$ \\
\hline b 4 & Association of beverage companies & October 16, 2019 \\
\hline \multicolumn{3}{|l|}{ Supermarkets } \\
\hline s 1 & Supermarket 1 & $\begin{array}{l}\text { October 16, } 2019 \\
\text { March 6, } 2020\end{array}$ \\
\hline s 2 & Supermarket 2 & March 4, 2020 \\
\hline s 3 & Supermarket 3 & March 4, 2020 \\
\hline \multicolumn{3}{|l|}{$N G O s$} \\
\hline n 1 & NGO 1 & $\begin{array}{l}\text { October 29, } 2019 \\
\text { February 26, } 2020\end{array}$ \\
\hline n 2 & NGO 2 & $\begin{array}{l}\text { October 22, } 2019 \\
\text { March 05, } 2020\end{array}$ \\
\hline n 3 & NGO 3 & October 25, 2019 \\
\hline n 4 & NGO 4 & October 28, 2019 \\
\hline n 5 & NGO 5 & October 31, 2019 \\
\hline \multicolumn{3}{|l|}{ Academia } \\
\hline a 1 & Think tank & October 22, 2019 \\
\hline a 2 & University & October 28, 2019 \\
\hline
\end{tabular}

Acknowledgements We would like to thank Babette Never from the German Development Institute for her valuable comments and support. Finally, we are grateful to all our interviewees for their time, cooperation and the knowledge they shared with us.

Author Contribution The authors contributed equally to the paper.

Funding Open Access funding enabled and organized by Projekt DEAL. We are grateful to the German Federal Ministry of Education and Research (BMBF) for funding the study.

Data Availability N/A.

Code Availability N/A. 


\section{Declarations}

Ethics Approval N/A

Consent to Participate N/A

Consent for Publication N/A

Competing Interests The authors declare no competing interests.

Open Access This article is licensed under a Creative Commons Attribution 4.0 International License, which permits use, sharing, adaptation, distribution and reproduction in any medium or format, as long as you give appropriate credit to the original author(s) and the source, provide a link to the Creative Commons licence, and indicate if changes were made. The images or other third party material in this article are included in the article's Creative Commons licence, unless indicated otherwise in a credit line to the material. If material is not included in the article's Creative Commons licence and your intended use is not permitted by statutory regulation or exceeds the permitted use, you will need to obtain permission directly from the copyright holder. To view a copy of this licence, visit http://creativecommons.org/licenses/by/4.0/.

\section{References}

1. MINAM (2020). Portal Regional SINIA - Estadística ambiental. Retrieved from: https://sinia. minam.gob.pe/informacion/tematicas?tematica=08 (06.07.21).

2. Hofstetter JS, De Marchi V, Sarkis J et al (2021) From sustainable global value chains to circular economy-different silos, different perspectives, but many opportunities to build bridges. Circular Economy and Sustainability 1:21-47. https://doi.org/10.1007/s43615-021-00015-2

3. Tsai FM, Bui T-D, Tseng M-L, Lim MK, Hu J (2020) Municipal solid waste management in a circular economy: a data-driven bibliometric analysis. J Clean Prod 275:124132. https://doi.org/10. 1016/j.jclepro.2020.124132

4. Menikpura SNM, Gheewala SH, Bonnet S, Chiemchaisri C (2013) Evaluation of the effect of recycling on sustainability of municipal solid waste management in Thailand. Waste and Biomass Valorization 4(2):237-257. https://doi.org/10.1007/s12649-012-9119-5

5. DEFRA (2011). Government review of waste policy in England 2011.

6. Mancini SD, de Medeiros GA, Paes MX, de Oliveira BOS, Antunes MLP, de Souza RG, Ferraz JL, Bortoleto AP, de Oliveira JAP (2021) Circular economy and solid waste management: challenges and opportunities in Brazil. Circular Economy and Sustainability. https://doi.org/10.1007/ s43615-021-00031-2

7. INEI (2019a). Registro Nacional de Municipalidades 2019. INEI.

8. Defensoría del Pueblo (2019). ¿Dónde va nuestra basura? Recomendaciones para mejorar la gestión de los residuos sólidos municipales. Informe Defensorial $N^{\circ} 181$. Retrieved from: https://www. defensoria.gob.pe/wp-content/uploads/2019/11/INFORME-DEFENSORIAL-181.pdf (06.07.21).

9. Matter A, Ahsan M, Marbach M, Zurbrügg C (2015) Impacts of policy and market incentives for solid waste recycling in Dhaka, Bangladesh. Waste Manage 39:321-328. https://doi.org/10.1016/j. wasman.2015.01.032

10. Stoeva K, Alriksson S (2017) Influence of recycling programmes on waste separation behaviour. Waste Manage 68:732-741. https://doi.org/10.1016/j.wasman.2017.06.005

11. INEI (2004). Encuesta Nacional de Hogares sobre condiciones de vida y pobreza 2004. INEI.

12. INEI (2019b). Encuesta Nacional de Hogares sobre condiciones de vida y pobreza 2019. INEI.

13. Reardon T, Timmer CP, Barrett CB, Berdegué J (2003) The rise of supermarkets in Africa, Asia, and Latin America. Am J Agr Econ 58(5):1140-1146. https://doi.org/10.1111/j.0092-5853.2003. 00520.x

14. Never, B., Albert, J.R., Fuhrmann, H., Gsell, S., Jaramillo, M., Kuhn, S. \& Senadza, B., 2020. Carbon-intensity of consumption patterns of the emerging middle classes. DIE Discussion Paper, 10-2020, Bonn: Deutsches Institut für Entwicklungspolitik (DIE). 
15. De la Cruz, R., Manzano, O., Loterszpil, M., Castilleja-Vargas, L., \& Deza, M. C. (2020). Cómo acelerar el crecimiento económico y fortalecer la clase media: Perú. Inter-American Development Bank.

16. Jones P, Hillier D, Comfort D, Eastwood I (2005) Sustainable retailing and consumerism. Manag Res News 28(1):34-44. https://doi.org/10.1108/01409170510784760

17. Ruiz-Real J, Uribe-Toril J, Gázquez-Abad J, de Pablo Valenciano J (2019) Sustainability and retail: analysis of global research. Sustainability 11(1):14. https://doi.org/10.3390/su11010014

18. Altenburg, T., Kulke, E., Hampel-Milagrosa, A., Peterskovsky, L., \& Reeg, C. (2016). Making retail modernisation in developing countries inclusive. A development policy perspective. DIE Discussion Paper, 2-2016, Bonn: Deutsches Institut für Entwicklungspolitik (DIE).

19. Lee KCL (2018) Grocery shopping, food waste, and the retail landscape of cities: the case of Seoul. J Clean Prod 172:325-334. https://doi.org/10.1016/j.jclepro.2017.10.085

20. Orihuela, J.C. (2018). Un análisis de la eficiencia de la gestión municipal de residuso sólidos en el Perú y sus determinantes. Instituto Nacional de Estadística e Informática (INEI).

21. Rateau, M., \& Tovar, L. (2019). Formalization of waste pickers in Bogota and Lima: recognize, regulate, and then integrate? Echogeo, 47https://doi.org/10.4000/echogeo.16614

22. Ciudad Saludable (2018). Inclusive waste management in Peru: enabling the business of recycling. Retrieved from: https://www.mastercardcenter.org/content/dam/mc-cig/uploads/Inclusive-WasteMgmt-in-Peru-March-2018.pdf (06.07.21).

23. Harvey P (2017) Waste futures: infrastructures and political experimentation in Southern Peru. Ethnos 82(4):672-689. https://doi.org/10.1080/00141844.2015.1108351

24. Madueño, D. (2012). El proceso de formalización de los recicladores y la reproducción de las condiciones de desigualdad en la microempresa Fuerza Emprendedora Lima Norte (FELN). IEP. http:// repositorio.iep.org.pe/handle/IEP/953

25. Durand M, Metzger P (2009) Gestión de residuos y transferencia de vulnerabilidad en Lima/Callao. Bifea 38(3):623-646. https://doi.org/10.4000/bifea.2396

26. Chong A, Karlan D, Shapiro J, Zinman J (2013) (Ineffective) Messages to encourage recycling: evidence from a randomized evaluation in Peru. The World Bank Economic Review 29(1):180-206. https://doi.org/10.1093/wber/lht022

27. Nikolaou IE, Jones N, Stefanakis A (2021) Circular economy and sustainability: the past, the present and the future directions. Circular Economy and Sustainability. https://doi.org/10.1007/ s43615-021-00030-3

28. Dubois A, Gadde L-E (2002) Systematic combining: an abductive approach to case research. J Bus Res 55(7):553-560. https://doi.org/10.1016/S0148-2963(00)00195-8

29. Timmermans S, Tavory I (2012) Theory construction in qualitative research: from grounded theory to abductive analysis. Sociol Theory 30(3):167-186. https://doi.org/10.1177/0735275112457914

30. Baah C, Afum E, Agyabeng-Mensah Y, Agyeman DO (2021) Stakeholder influence on adoption of circular economy principles: measuring implications for satisfaction and green legitimacy. Circular Economy and Sustainability. https://doi.org/10.1007/s43615-021-00093-2

31. United Nations Environment Programme. (2018). Waste management outlook for Latin America and the Caribbean.

32. Massoud M, El-Fadel M (2002) Public-private partnerships for solid waste management services. Environ Manage 30(5):621-630. https://doi.org/10.1007/s00267-002-2715-6

33. Dai YC, Gordon MPR, Ye JY, Xu DY, Lin ZY, Robinson NKL, Woodard R, Harder MK (2015) Why doorstepping can increase household waste recycling. Resour Conserv Recycl 102:9-19. https://doi. org/10.1016/j.resconrec.2015.06.004

34. Carlson AE (2001) Recycling norms. Calif Law Rev 89(5):1231. https://doi.org/10.2307/3481159

35. Miafodzyeva S, Brandt N (2013) Recycling behaviour among householders: synthesizing determinants via a meta-analysis. Waste Biomass Valor 4(2):221-235. https://doi.org/10.1007/s12649-012-9144-4

36. Zhang S, Zhang M, Yu X, Ren H (2016) What keeps Chinese from recycling: accessibility of recycling facilities and the behavior. Resour Conserv Recycl 109:176-186. https://doi.org/10.1016/j.resconrec. 2016.02.008

37. Strydom W (2018) Barriers to household waste recycling: empirical evidence from South Africa. Recycling 3(3):41. https://doi.org/10.3390/recycling3030041

38. Martin M, Williams ID, Clark M (2006) Social, cultural and structural influences on household waste recycling: a case study. Resour Conserv Recycl 48(4):357-395. https://doi.org/10.1016/j.resconrec. 2005.09.005

39. Srivastava M, Kaul D (2014) Social interaction, convenience and customer satisfaction: the mediating effect of customer experience. J Retail Consum Serv 21(6):1028-1037. https://doi.org/10.1016/j.jretc onser.2014.04.007 
40. Ipsos. (2016). Peru 2017, From informality to modernity.

41. Khan F, Ahmed W, Najmi A (2019) Understanding consumers' behavior intentions towards dealing with the plastic waste: perspective of a developing country. Resour Conserv Recycl 142:49-58. https:// doi.org/10.1016/j.resconrec.2018.11.020

42. Lawrence K, Cooper V, Kissoon P (2020) Sustaining voluntary recycling programmes in a country transitioning to an integrated solid waste management system. J Environ Manage 257:109966. https:// doi.org/10.1016/j.jenvman.2019.109966

43. Hage O, Sandberg K, Söderholm P, Berglund C (2018) The regional heterogeneity of household recycling: a spatial-econometric analysis of Swedish plastic packing waste. Lett Spat Resour Sci 11(3):245-267. https://doi.org/10.1007/s12076-017-0200-3

44. Sidique SF, Lupi F, Joshi SV (2010) The effects of behavior and attitudes on drop-off recycling activities. Resour Conserv Recycl 54(3):163-170. https://doi.org/10.1016/j.resconrec.2009.07.012

45. Lange F, Brückner C, Kröger B, Beller J, Eggert F (2014) Wasting ways: perceived distance to the recycling facilities predicts pro-environmental behavior. Resour Conserv Recycl 92:246-254. https:// doi.org/10.1016/j.resconrec.2014.07.008

46. Fuhrmann-Riebel H, D'Exelle B, Verschoor A (2021) The role of preferences for pro-environmental behaviour among urban middle class households in Peru. Ecol Econ 180:106850

47. Iyer ES, Kashyap RK (2007) Consumer recycling: role of incentives, information, and social class. J Consum Behav 6(1):32-47. https://doi.org/10.1002/cb.206

48. Young CW, Russell SV, Robinson CA, Chintakayala PK (2017) Sustainable retailing - influencing consumer behaviour on food waste. Bus Strat Env 27(1):1-15. https://doi.org/10.1002/bse.1966

49. Ohtomo S, Ohnuma S (2014) Psychological interventional approach for reduce resource consumption: reducing plastic bag usage at supermarkets. Resour Conserv Recycl 84:57-65. https://doi.org/10. 1016/j.resconrec.2013.12.014

50. Gupta, K. (2011). Consumer responses to incentives to reduce plastic bag use: evidence from a field experiment in urban India. SANDEE working papers, 65-11. Kathmandu: SANDEE.

51. Hansmann R, Bernasconi P, Smieszek T, Loukopoulos P, Scholz RW (2006) Justifications and selforganization as determinants of recycling behavior: the case of used batteries. Resour Conserv Recycl 47(2):133-159. https://doi.org/10.1016/j.resconrec.2005.10.006

52. Jen MY, Wang S (2015) Understanding the purchasing behaviour of Taiwanese meat consumers in light of rising sustainability concerns. British Food Journal 117(5):1474-1487. https://doi.org/10. 1108/bfj-06-2014-0193

53. Schultz PW (1999) Changing behavior with normative feedback interventions: a field experiment on curbside recycling. Basic Appl Soc Psychol 21(1):25-36. https://doi.org/10.1207/s15324834basp21 01_3

54. Crociata A, Agovino M, Sacco PL (2016) Neighborhood effects and pro-environmental behavior: the case of Italian separate waste collection. J Clean Prod 135:80-89. https://doi.org/10.1016/j.jclepro. 2016.06.083

55. Varotto A, Spagnolli A (2017) Psychological strategies to promote household recycling. A systematic review with meta-analysis of validated field interventions. J Environ Psychol 51:168-188. https://doi. org/10.1016/j.jenvp.2017.03.011

56. Cialdini R, Kallgren CA, Reno RR (1991) A focus theory of normative conduct: a theoretical refinement and reevaluation of the role of norms in human behavior. Adv Exp Soc Psychol 24:201-234. https://doi.org/10.1016/S0065-2601(08)60330-5

57. Cicatiello C, Pancino B, Pascucci S, Franco S (2015) Relationship patterns in food purchase: observing social interactions in different shopping environments. J Agric Environ Ethics 28(1):21-42. https:// doi.org/10.1007/s10806-014-9516-9

58. Witzling L, Shaw B, Trechter D (2019) Which communication channels shape normative perceptions about buying local food? An application of social exposure. Agric Hum Values 36(3):443-454. https:// doi.org/10.1007/s10460-019-09926-1

59. Thomas C, Sharp V (2013) Understanding the normalisation of recycling behaviour and its implications for other pro-environmental behaviours: a review of social norms and recycling. Resour Conserv Recycl 79:11-20. https://doi.org/10.1016/j.resconrec.2013.04.010

60. Testa F, Russo MV, Cornwell TB, McDonald A, Reich B (2018) Social sustainability as buying local: effects of soft policy, meso-level actors, and social influences on purchase intentions. J Public Policy Mark 37(1):152-166. https://doi.org/10.1509/jppm.16.215

61. Botetzagias I, Dima A-F, Malesios C (2015) Extending the theory of planned behavior in the context of recycling: the role of moral norms and of demographic predictors. Resour Conserv Recycl 95:5867. https://doi.org/10.1016/j.resconrec.2014.12.004 
62. Pryor C, Perfors A, Howe PDL (2019) Even arbitrary norms influence moral decision-making. Nat Hum Behav 3(1):57-62. https://doi.org/10.1038/s41562-018-0489-y

63. Li D, Zhao L, Ma S, Shao S, Zhang L (2019) What influences an individual's pro-environmental behavior? A literature review. Resour Conserv Recycl 146:28-34. https://doi.org/10.1016/j.resconrec. 2019.03.024

64. Bilz, K., \& Nadler, J. (2014). Law, moral attitudes, and behavioral change. In: E. Zamir \& D. Teichman (Eds.), The Oxford Handbook of Behavioral Economics and the Law. Oxford University Press.

65. Zen IS (2020) Plastic bag ban in the context of corporate social responsibility: consumption and trade vis-a'-vis environmental sustainability concerns. In: Filho WL, de Brito PRB, Frankenberger F (eds) International Business, Trade and Institutional Sustainability World Sustainability Series. Springer International Publishing, pp 43-68

66. Kaplan Mintz K, Henn L, Park J, Kurman J (2019) What predicts household waste management behaviors? Culture and type of behavior as moderators. Resour Conserv Recycl 145:11-18

67. Ferronato N, Rada EC, Gorritty Portillo MA, Cioca LI, Ragazzi M, Torretta V (2019) Introduction of the circular economy within developing regions: a comparative analysis of advantages and opportunities for waste valorization. J Environ Manage 230:366-378. https://doi.org/10.1016/j.jenvman.2018. 09.095

68. Schröder, P., Albaladejo, M., Alonso Ribas, P., MacEwen, M., \& Tilkanen, J. (2020). The circular economy in Latin America and the Caribbean. Retrieved from: https://www.chathamhouse.org/2020/ 09/circular-economy-latin-america-and-caribbean (06.07.21).

69. Arca Continental Lindley (2020). Reporte de Sostenibilidad Corporativa, Sección B.

70. Loschelder DD, Siepelmeyer H, Fische D, Rubel JA (2019) Dynamic norms drive sustainable consumption: norm-based nudging helps café customers to avoid disposable to-go-cups. J Econ Psychol 75(Part A):102146. https://doi.org/10.1016/j.joep.2019.02.002

71. Fuhrmann-Riebel, H., D'Exelle, B., López Vargas, K., Tonke, S. \& Verschoor, A. (2021). "Boosting recycling behaviour among urban households in Peru - a field experiment on the role of social norms and beliefs." AEA RCT Registry. May 25. https://doi.org/10.1257/rct.7063-2.0

72. Abrahamse W, Steg L (2013) Social influence approaches to encourage resource conservation: a metaanalysis. Glob Environ Chang 23:1773-1785. https://doi.org/10.1016/j.gloenvcha.2013.07.029 